\title{
Role of the uterus in early regression of corpora lutea induced by the ram effect in seasonally anoestrous Barbarine ewes
}

\author{
N Lassoued ${ }^{1 *}$, G Khaldi ${ }^{1}$, P Chemineau ${ }^{2}$, \\ Y Cognié ${ }^{2}$ J Thimonier ${ }^{3}$
}

\author{
'Laboratoire des recherches ovines et caprines, Inrat, 2080 Ariana, Tunisia; \\ ${ }^{2}$ Physiologie de la reproduction des mammiferes domestiques, Inra, 37380 Nouzilly; \\ ${ }^{3}$ Chaire de zootechnie, Ensa M-Inra, place Viala, 34060 Montpellier cedex, France
}

(Received 31 August 1996; accepted 11 August 1997)

\begin{abstract}
Summary - The involvement of the uterus in early regression of corpora lutea induced by the ram effect was studied in seasonally anoestrous Barbarine ewes. In experiment 1 , group I was only submitted to the male effect (control, $n=15$ ) while group II ( $n=14$ ) was injected every $12 \mathrm{~h}$ with flunixin meglumine, a PGF2 $\alpha$ synthetase inhibitor (finadyne), from day 3 to day 6 (day 0 : day of ram introduction). The preovulatory LH surge appeared at the same time (around $21 \mathrm{~h}$ after ram introduction) in both groups. Finadyne treatment significantly decreased 13-14-dihydro-15-keto-PGF2 $\alpha$ (PGFM) pulses $(1.3 \pm 0.3$ versus $0.4 \pm 0.2 ; P<0.05)$, the number of short cycles $(50$ versus $14 \%, P$ $<0.05$ ), and provided a single peak of oestrus, 15-16 days after the introduction of the rams, instead of between day 14 and day $23(P<0.01)$. In experiment 2,17 hysterectomized ewes were allocated into two groups: group III $(n=8)$ was injected with oil and group IV $(n=9)$ received an intramuscular injection of $20 \mathrm{mg}$ of progesterone immediately before introduction of rams. An additional group of intact ewes was used as control (group V, $n=9$ ). Hysterectomy did not affect the ovulation response to the ram effect, but completely suppressed short cycles $(0$ versus $78 \%, P<0.001)$. The preovulatory $\mathrm{LH}$ surge was delayed in hysterectomized females $(36.0 \pm 14.1$ versus $16.6 \pm 11.4 \mathrm{~h} ; P$ $<0.004)$. Treatment with progesterone significantly $(P<0.01)$ increased the interval between introduction of rams and the preovulatory LH surge. In conclusion, suppression of short cycles by hysterectomy and an inhibitor of PGF2 $\alpha$ synthetase suggest that the uterus is essential for determining the lifespan of ram-induced corpora lutea and that premature release of PGF2 $\alpha$ is the cause of early luteal regression. The hypothesis that lower secretion of progesterone before D5 could be the initial cause of the premature induction of the luteolytic signal is discussed.
\end{abstract}

ram effect / corpus luteum lifespan / hysterectomy / prostaglandin / ewe

\footnotetext{
* Correspondence and reprints
} 
Résumé - Rôle de l'utérus dans la régression précoce des corps jaunes induits par effet bélier chez des brebis de race Barbarine en anœstrus saisonnier. L'implication de l'utérus dans la régression lutéale précoce des corps jaunes a été étudiée chez des brebis de race Barbarine soumises à l'effet bélier pendant l'anœstrus saisonnier. Une première expérience concerne deux lots de brebis : les femelles du lot I sont seulement soumises à l'effet mâle (lot témoin, $n=15$ ); celles du lot II $(n=14)$ reçoivent, toutes les $12 \mathrm{~h}$, un inhibiteur de la synthèse des PGF2 $\alpha$ (finadyne), de J3 à J6 (J0 étant le jour d'introduction des béliers). Un pic préovulatoire de LH apparaît environ $21 \mathrm{~h}$ après introduction des béliers chez la quasi-totalité des femelles des deux lots. Le traitement à la finadyne diminue significativement le nombre de pulses de 13-14-dihydro-15-céto-PGF2 $\alpha$ (PGFM : 1,3 \pm $0,3$ vs $0,4 \pm 0,2 ; p<0,05)$, diminue également la fréquence d'apparition des cycles courts (50 vs $14 \%, p<0,01$ ) et permet ainsi une synchronisation des chaleurs à $\mathrm{J} 15$ et J16 au lieu d'un étalement entre $\mathrm{J} 14$ et $\mathrm{J} 23$ dans le lot témoin $(p=0,01)$. La deuxième expérience concerne 17 brebis hystérectomisées et réparties en deux groupes : les brebis du lot III $(n=8)$ sont injectées avec de l'huile et celles du lot IV $(n=9)$ reçoivent une injection intramusculaire de $20 \mathrm{mg}$ de progestérone immédiatement avant l'introduction des béliers. Des femelles intactes servent de témoins (lot $\mathrm{V}, n=9)$. L'hystérectomie n'affecte pas le pourcentage de femelles ovulant après l'effet bélier mais supprime totalement l'apparition des cycles courts ( 0 vs $78 \%, p<0,001)$. Le pic préovulatoire de LH est plus tardif $(p<$ $0,004)$ chez les brebis hystérectomisées $(36,0 \pm 14,1 \mathrm{~h})$ que chez les brebis témoins $(16,6 \pm 11,4 \mathrm{~h})$. L'injection préalable de progestérone augmente encore l'intervalle introduction des béliers-pic préovulatoire de $\mathrm{LH}(p<0,01)$. En conclusion, la suppression des cycles courts soit par un inhibiteur de la synthèse des prostaglandines $F 2 \alpha$, soit par hystérectomie met en évidence le rôle essentiel que jouent l'utérus et particulièrement les prostaglandines dans la régression prématurée des corps jaunes induits par effet mâle chez des femelles en anœstrus saisonnier. L'hypothèse qu'une plus faible concentration de progestérone avant $\mathbf{J} 5$ pourrait être la cause initiale de la mise en place du signal lutéolytique est également discutée.

effet mâle / corps jaune / hystérectomie / prostaglandine / brebis

\section{INTRODUCTION}

Introduction of a male to a group of previously isolated anovulatory ewes or goats can induce oestrus and ovarian activity. The induced ovulation occurs within the first 4 days following exposure (ewe: Knight et al, 1978; goat: Chemineau, 1983). Such induced corpora lutea often have a short lifespan and exhibit early regression after transitory progesterone release (Knight et al, 1981; Chemineau, 1983). The proportion of short cycles varies and depends on factors such as nutrition, season and breed, all of which may affect the 'depth' of anoestrus (goat: Chemineau, 1983; ewe: Khaldi, 1984; Lassoued and Khaldi, 1993). In all cases, the length of these cycles is less than 7 days (Oldham, 1980; Knight et al, 1981; Chemineau, 1983; Southee et al, 1988; Lassoued and Khaldi, 1993; Lassoued et al, 1995).
The mechanism of short cycles induced by the male effect in anoestrous females is still unknown and little work has been carried out on the subject. Early regression could be attributed to the lack of maturity of preovulatory follicles (Cognié et al, 1982; Lindsay et al, 1982; Martin et al, 1983). However, this hypothesis does not explain why this regression occurs at a definite stage of the cycle, which corresponds to the beginning of the sensitivity of the corpus luteum to prostaglandin injections (Acritopoulou and Haresign, 1980). If it were only a matter of follicular maturity, the luteal phases should be of variable periods between 2 and 13 days.

Hypothesis of higher sensitivity of hypofunctional corpora lutea to PGF2 $\alpha$ is less probable owing to the fact that the corpora lutea induced by $\mathrm{GnRH}$ are not more sensitive to the luteolytic action of prostaglandin F2 $\alpha$ than those having normal lifespan 
(Copelin et al, 1988). If such an effect is also valid for corpora lutea induced by the ram effect, then we have to suppose that their early regression is related to trophic factor insufficiency and/or to the early release of luteolytic factors.

Priming with a single injection of $20 \mathrm{mg}$ of progesterone, or with a progestagen for several days, eliminates these abnormal ovarian cycles (Cognié et al, 1982; McLeod and Haresign, 1984). Progesterone may act on the hypothalamic-pituitary pathway (Martin et al, 1983), or at the level of the ovary (Hunter et al, 1986; Brown et al, 1988) or uterus. This latter suggestion has been widely studied (Vallet et al, 1990).

Corpus luteum regression depends on PGF2 $\alpha$ as the uterine luteolysin, the surge of which increases rapidly following coupling of oxytocin to its receptor in the endometrium (McCracken et al, 1984). This release is correlated to oxytocin receptor concentrations in the endometrium (Flint et al, 1990). Maximum concentrations occur during oestrus, and are lower, relatively, 4 to 5 days earlier or later (Roberts et al, 1976; Sheldrick and Flint, 1985). During oestrus, plasma concentrations of progesterone are minimal whereas oestradiol concentrations are maximal, suggesting that oxytocin receptor synthesis is inhibited by progesterone (Hunter et al, 1989; Vallet et al, 1990) and increased by oestradiol (Hixon and Flint, 1987).

Various studies have highlighted the role of uterine PGF $2 \alpha$ in the early regression of induced corpora lutea. In seasonally anovular ewes, hysterectomy prolongs the lifespan of the corpus luteum after GnRHinduced ovulation (Southee et al, 1988) or those induced by the male effect (Chemineau et al, 1993). Injected into the uterus as late as day 12 (ewe) or day 14 (heifer) of the oestrous cycle, indomethacin inhibition of PGF2 $\alpha$ synthesis, prevented normal luteal regression (Lewis and Warren, 1977). In Barbarine ewes, when ovulation is induced by the male effect, treatment with indomethacin is less efficient, it reduces the frequency of short ovulatory cycles by $30 \%$. The lifespan of hypofunctional corpora lutea is extented by 2 days and the concentration of progesterone in plasma is increased (Lassoued and Khaldi, 1989).

The objective of this study was to use a more efficient inhibitor of prostaglandin secretion (finadyne, Battye et al, 1988), and to assess the luteal activity in hysterectomized ewes treated or not with progesterone to evaluate the trophic action of this hormone on the induced corpora lutea.

\section{MATERIAL AND METHODS}

\section{Animals and treatments}

Two experiments were conducted in May during 1989-1991 at Inra-Tunisia using adult Barbarine ewes with fat tail; spring is the period of lowest sexual activity (Khaldi, 1984). For both experiments, females were isolated from males for more than 2 months. Adult Barbarine rams were introduced into the flock at a ratio of one male to ten females. Day 0 (D0) was defined as the first day of ram introduction. Beginning on D0 detection of oestrus was carried out twice daily, morning and afternoon, for 1 month.

The work of Khaldi (1984) showed that there is a close relationship between the proportion of short cycles and the ewes liveweight 2 months before mating. This proportion can reach $67 \%$ when the body weight is lower than $42 \mathrm{~kg}$. To obtain similar live weight evolution, feeding restriction was initiated at the end of pregnancy and continued up to mating. The food quantity was controlled according to the weight progress measured every 10 days. Initially, animals were raised on summer stubbles supplemented with hay ad libitum plus $300 \mathrm{~g}$ of concentrate.

\section{Experiment 1}

Twenty-nine anovulatory ewes (observed by coelioscopy at D-1) were divided into two homogeneous groups (I and II) according to liveweight (respectively, $41.9 \pm 3.7$ and $42.1 \pm 5.1 \mathrm{~kg}$ ) and age (2-6 years): group I: untreated control females $(n=15)$; group II: females receiving an 
intramuscular injection of Flunixin Meglumine, an inhibitor of PGF $2 \alpha$ synthetase (finadyne, Rigaux Galéna, France) at a dose rate of 2.2 $\mathrm{mg} / \mathrm{kg} /$ female at 12 -h intervals. Treatment began at D3 and was continued for 4 days until D6 $(n=$ 14).

\section{Experiment 2}

Seventeen ewes, hysterectomized for more than 1 year, and weighing $41.2 \pm 2.7 \mathrm{~kg}$ were injected intramuscularly, on D-7, with a luteolytic dose of prostaglandin F2 $\alpha$ analog (1.25 mg of Prostavet, Virbac, France), in order to synchronize the timing of luteal regression. The absence of a corpus luteum before the ram effect was assessed by plasma progesterone concentrations (Thimonier, 1978) on D-1 and D0.

The ewes were divided into two homogeneous groups (groups III and IV) according to liveweight (respectively, $40.9 \pm 3.2$ and $41.7 \pm$ $2.3 \mathrm{~kg})$ and age (2-6 years): group III $(n=8)$ were untreated control females; group IV $(n=$ 9) females received an intramuscular injection of $20 \mathrm{mg}$ progesterone (Sigma, France) immediately before ram introduction; group V $(n=9)$ were intact anovulatory ewes (coelioscopy on D-1) weighing $36.9 \pm 3.3 \mathrm{~kg}$.

After the analysis of progesterone concentrations, two females of group III were discarded because they showed spontaneous ovulatory activity before male contact.

\section{Samples, hormonal assays and ovarian dynamics}

\section{Blood samples}

To determine the occurrence of preovulatory $\mathrm{LH}$ surge, blood was collected by jugular venepuncture at 4-h intervals for $76 \mathrm{~h}$ following male introduction.

Blood samples for progesterone assays were taken daily from D1 until D17 (experiment 1: groups I and II; experiment 2: groups III and IV) and from D1 until D8 only for group V in experiment 2.

The 13-14-dihydro-15-keto-PGF2 $\alpha$ (PGFM) concentrations were estimated in blood samples collected hourly on D4 and D5 between 0900 and 1700 hours. Under our conditions, pulse detection was carried out using the Munroe algo- rithm (Merriam and Wachter, 1982). Ewes with a late preovulatory surge were discarded.

The blood was centrifuged and the plasma stored at $-20^{\circ} \mathrm{C}$ until assayed.

\section{Hormone radioimmunoassays}

Concentrations of $\mathrm{LH}$, progesterone and PGFM were determined by radioimmunoassay.

Plasma LH concentrations were determined using the method of Pelletier et al (1982) and modified by Montgomery et al (1985). The limit of sensitivity of the assay was $0.1 \mathrm{ng} / \mathrm{mL}$ and the inter- and intra-assay coefficients of variation were 10.1 and $11.3 \%$, respectively.

The time of the initiation of the preovulatory surge of LH was considered as the point of the first $\mathrm{LH}$ concentration higher than $10 \mathrm{ng} / \mathrm{mL}$, and the moment of ovulation $24 \mathrm{~h}$ later.

Progesterone assay was performed using kits supplied by IAEA (Vienna, Austria). The sensitivity of this method was $0.09 \mathrm{ng} / \mathrm{mL}$ and the inter- and intra-assay coefficients of variation were 9.2 and $11.0 \%$, respectively.

The estimation of PGFM concentration in the blood is a direct reflection of PGF2 $\alpha$ release by the uterus (Peterson et al, 1976; Zarco et al, 1984). PGFM was assayed according to the method of Dray et al (1980). The assay sensitivity was $0.4 \mathrm{pg} / 100 \mu \mathrm{L}$ and intra- and inter-assay coefficients of variation were 10 and $11 \%$, respectively.

\section{Ovarian dynamics}

Coeslioscopy was carried out on D4 (experiment 1: groups I and II), D9, and 8-12 days following first oestrus (experiment 1: groups I and II, experiment 2: group V) in order to define the day of ovulation onset according to the criteria proposed by Oldham and Lindsay (1980) and to determine the number of corpora lutea (ovulation rate). In the case of hysterectomized ewes (experiment 2: groups III and IV), ovary observation using coelioscopy is difficult and therefore plasma progesterone levels were used as an indicator of ovulation and luteal activity. Cycles were classified as short when the induced corpus luteum regressed within 5 days. Only ewes with nonfunctional or regressed corpora lutea on $\mathrm{D}-1$ were considered anovulatory or non-cyclic. 


\section{Statistical analysis}

Data were analysed using SAS software (Statistical Analysis System Institut). The results of the hormone assays (progesterone and PGFM) were analysed using a three-factor analysis of variance (ewe, treatment, prelevement). Comparison between groups were carried out using Duncan's multiple range test. Chi-square analysis was used to compare ovulation rate, short cycle frequencies, LH surge start point and day of the onset of first oestrus. Data are expressed as mean \pm standard deviation (SD).

\section{RESULTS}

\section{Inhibition of PGF secretion}

Concentration and pulse frequency of PGFM on D4 and D5 in the peripheral circulation were lower in ewes with normal cycles than in those with short cycles within each group and between groups (table I, $P<0.05)$.

Figure 1 shows the variation in plasma PGFM concentration for ewes with short and normal cycles. Mean concentrations were higher in short cycles compared to normal cycles (table I, $P<0.05$ ), but within each group the difference was not significant.

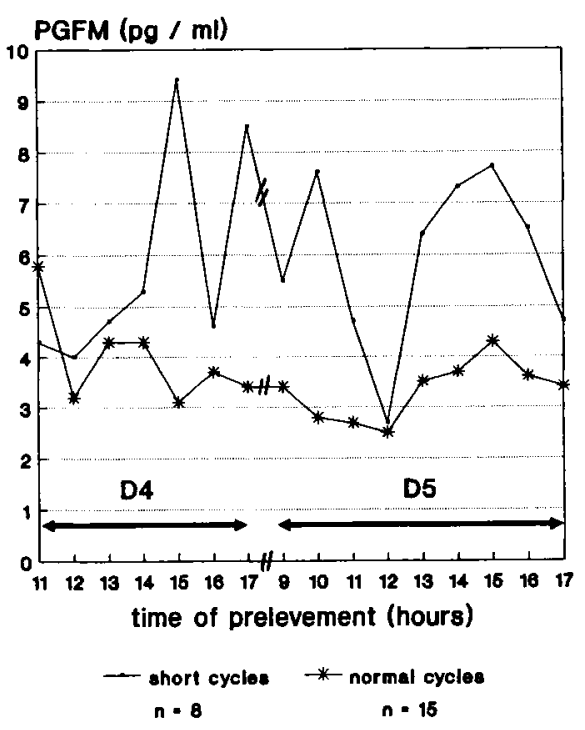

Fig 1. Plasma PGFM concentrations in short and normal cycles at D4 and D5 after ram introduction.

The number of PGFM peaks was significantly higher in short cycles (table $\mathrm{I}, P<$ 0.05 ) and in the control group than in the finadyne-treated group $(1.3+0.3$ versus 0.4 $+0.2 ; P<0.05)$. Peaks of PGFM were detected in all ewes $(100 \%)$ that exhibited short cycles but only $20 \%$ of ewes with normal cycle showed one peak through the detection period.

Table I. Concentrations and pulse frequency of PGFM in both control and finadyne groups, and in females with short or normal induced cycles.

\begin{tabular}{lcccc}
\hline Groups & \multicolumn{2}{c}{ Concentration $(\mathrm{pg} / \mathrm{mL})$} & \multicolumn{2}{c}{ Number of pulses } \\
& Short cycles & Normal cycles & Short cycles & Normal cycles \\
\hline I (control) & $5.9 \pm 3.2$ & $2.9 \pm 0.6$ & $2.0 \pm 0.6 \mathrm{a}$ & $0 \mathrm{~b}$ \\
& $n=7$ & $n=4$ & $n=7$ & $n=4$ \\
II (finadyne) & 5.6 & $3.9 \pm 1.3$ & $2.0 \mathrm{a}$ & $0.3 \pm 0.4 \mathrm{~b}$ \\
& $n=1$ & $n=11$ & $n=1$ & $n=11$ \\
Total & $5.9 \pm 1.1 \mathrm{a}$ & $3.6 \pm 0.3 \mathrm{~b}$ & $2.0 \pm 0.2 \mathrm{a}$ & $0.2 \pm 0.1 \mathrm{~b}$ \\
& $n=8$ & $n=15$ & $n=8$ & $n=15$ \\
\hline
\end{tabular}

a versus b: $P<0.05$. 


\section{Preovulatory LH secretion}

\section{Experiment 1}

A preovulatory $\mathrm{LH}$ peak was detected in all females that ovulated. The mean time of onset of this peak was about $20 \mathrm{~h}$ after male introduction in groups I and II ( $18.5 \pm 10.8$ and $20.0 \pm 14.6 \mathrm{~h}$, respectively). Four days after male introduction, one or more corpora lutea were observed by coelioscopy in each of the females that responded to the male effect. Ovulations occurred between D1 and D3.

\section{Experiment 2}

The preovulatory LH surge occurred within $11.6 \pm 7.8 \mathrm{~h}$ in intact females (group V), and later in hysterectomized females which did not receive progesterone (group III: 33.6 $\pm 13.3 \mathrm{~h} ; P<0.004$ ). For females of group IV (injected with $20 \mathrm{mg}$ of progesterone immediately before ram introduction), no LH surge had been detected up to $76 \mathrm{~h}$. The initiation of the LH surge probably occurred after $76 \mathrm{~h}$. Hysterectomy significantly delayed the initiation of the preovulatory LH surge in comparison to intact females. This result was confirmed by subsequent analysis of progesterone profiles.

\section{Ovarian activity}

\section{Ovulation rate}

The ovulation rate accompanying the induced ovulation was higher when compared to the ovulation rate at first oestrus in groups I and II. However, the difference between the ovulation rates of the first and second ovulation was statistically significant only for the finadyne-treated females (table II; $P<0.05$ ).

\section{Progesterone levels}

\section{Experiment 1}

Only one ewe from the control group did not ovulate after ram introduction. When early luteal regression did not occur plasma progesterone concentrations increased gradually beginning at day 3 following ram introduction (fig $2 a, c$ ), reaching maximum values of approximately $3 \mathrm{ng} / \mathrm{mL}$ between D9 and D1 $13.16 \pm 0.77$ and $2.93 \pm 1.04$ $\mathrm{ng} / \mathrm{mL}$, respectively, for groups I and II). This concentration returned to low levels at D15 (group I) and D16 (group II). In cases of early luteal regression, short cycles were characterized by a brief increase in progesterone concentrations. The maximum level reached was at day 2 after ovulation in control group and day 3 in the finadyne group (fig $2 \mathrm{~b}, \mathrm{~d}$ ). At days 2 and 3 after ovulation, levels were always lower in short cycles than in normal cycles. This short luteal phase

Table II. Ovulatory response and luteal regression in ewes exposed to the ram effect alone (group I) or treated with finadyne (group II), $m \pm S D$.

\begin{tabular}{lccccc}
\hline Groups & $\begin{array}{c}\text { Number of } \\
\text { ewes }\end{array}$ & $\begin{array}{c}\text { Number of } \\
\text { ovulated ewes }\end{array}$ & $\begin{array}{c}\text { Number of } \\
\text { short cycles (\%) }\end{array}$ & $\begin{array}{c}\text { Ovulation rate } \\
\text { Induced }\end{array}$ & At first oestrus \\
\hline I (control) & 15 & 14 & $7(50) \mathrm{a}$ & $1.5 \pm 0.5$ & $1.3 \pm 0.5$ \\
II (finadyne) & 14 & 14 & $2(14) \mathrm{b}$ & $1.4 \pm 0.5 \mathrm{c}$ & $1.1 \pm 0.3 \mathrm{~d}$ \\
\hline
\end{tabular}

a versus b and c versus $\mathrm{d}: P<0.05$. 
Control group (I)

(a)

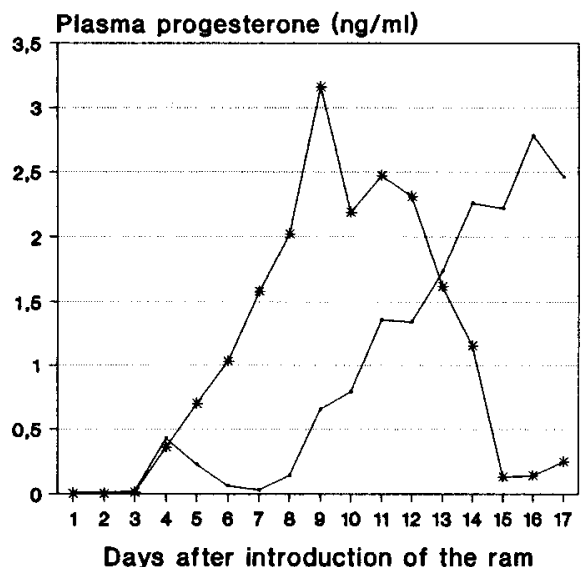

- short cyclea $\quad *$ normal cycles

$n=7 \quad n=7$

Finadyne group (II)

(c)

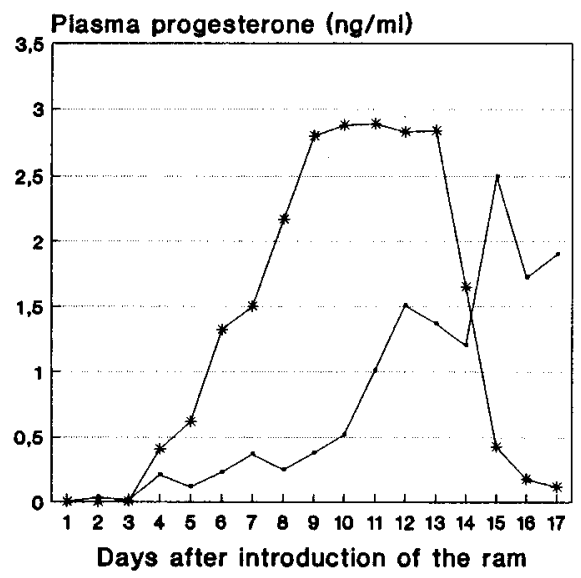

- short cycles $\rightarrow$ normal cycles

$n \cdot 2 \quad n \cdot 12$
Control group (I)

(b)

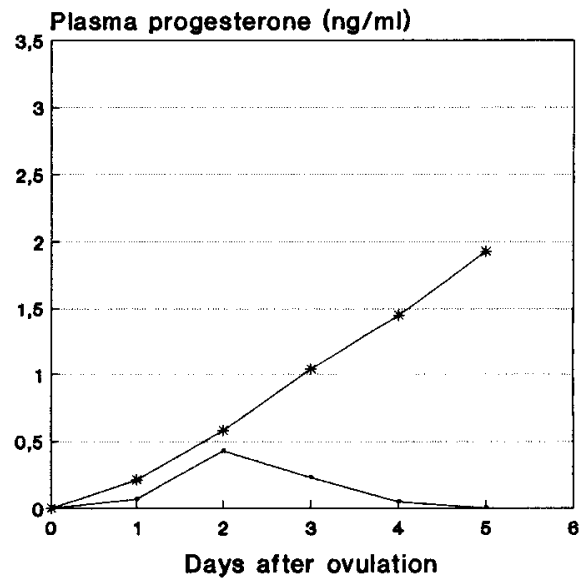

- short cycles $\rightarrow$ normal cycles

Finadyne group (II)

(d)

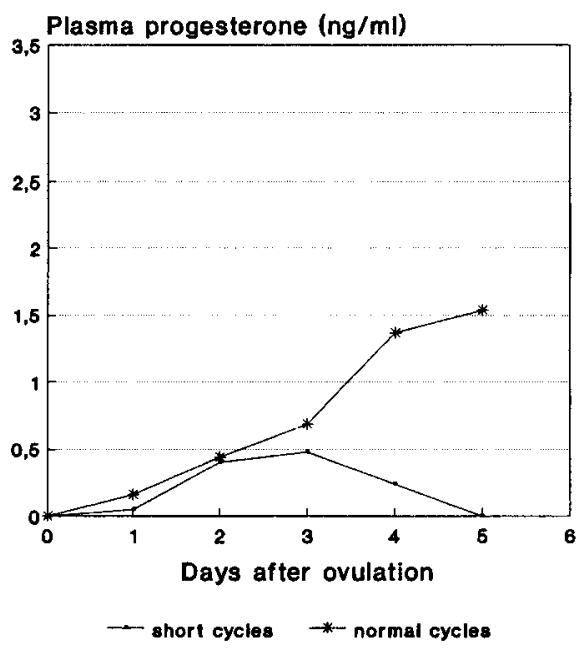

Fig 2. Plasma progesterone concentrations in control (group I) and finadyne-treated (group II) ewes after ram introduction $(a, c)$ and after induced ovulation $(b, d)$. 
was followed in all females (except for the one that entered anoestrous after ovulation induction, fig 2 b) by a new luteal phase similar to those of normal cycles.

\section{Experiment 2}

In hysterectomized ewes (group III), the increase in plasma progesterone was similar to that observed in intact females with normal cycles (group V). Nevertheless, levels of plasma progesterone were significantly lower in these females; mean levels between D1 and D8 after male introduction were 0.5 \pm 0.6 (group III) and $0.9 \pm 0.9 \mathrm{ng} / \mathrm{mL}$ (group $\mathrm{V} ; P<0.001$, fig $3 \mathrm{a}, \mathrm{c})$.

In hysterectomized ewes injected with $20 \mathrm{mg}$ progesterone (group IV), progesterone levels were over $1 \mathrm{ng} / \mathrm{mL}$ at D1 and decreased progressively. The minimum was reached on D5 with individual temporal variations. From that time, progesterone levels increased progressively until D11 and remained over $1.5 \mathrm{ng} / \mathrm{mL}$ (fig $3 \mathrm{c}$ ). In all hysterectomized females (groups III and IV), the luteal activity (plasma progesterone $>1$ $\mathrm{ng} / \mathrm{mL}$ ) was maintained at least up to D17.

Progesterone levels increased similarly in hysterectomized females (groups III and IV) from ovulation until day 8 (fig 3d).

\section{Corpora lutea lifespan}

\section{Experiment 1}

Regressed corpora lutea were found on the ovaries of $50 \%(7 / 14)$ of animals (table II) in the control group and only $14 \%(2 / 14)$ in the finadyne-treated group (group II versus group I: $P<0.05$ ).

These short cycles were followed by new ovulations as evidenced by plasma progesterone profiles and coelioscopy performed on $\mathrm{D} 9$. The length of the short cycles estimated by coelioscopy was around 5 days (groups I and II: $4.9 \pm 1.1$ and $4.5 \pm 0.7$ days) while normal cycles lasted 15-16 days
(15.0 \pm 1.0 and $15.7 \pm 0.8$ for ewes of groups I and II, respectively).

The progesterone levels were over 0.1 $\mathrm{ng} / \mathrm{mL}$ for approximately 12 days in normal cycles $(11.8 \pm 0.8$ and $11.8 \pm 1.3$ days for females of groups I and II, respectively) and about $2-3$ days in short cycles $(2.0 \pm 0$, group I; $2.5 \pm 0.7$ days, group II).

\section{Experiment 2}

No short cycles were observed in hysterectomized ewes. In contrast, these types of cycles were observed in $78 \%$ of females (7/9) in the intact control group (group III or IV versus group V: $P<0.001)$. In these cases, progesterone levels were over 0.1 $\mathrm{ng} / \mathrm{mL}$ for $3.1 \pm 0.7$ days.

\section{Onset of oestrus}

\section{Experiment 1}

All females in the control groups having ovulated after ram introduction, showed at least one oestrus. Only one female showed behavioural oestrus at induced ovulation (D1). All others showed first oestrus between D14 and D23. Oestrus behaviour was characterized by two peaks of activity in the flock, on days $14-16$ and $20-23$ postjoining (fig 4).

Only one treated female (group II) did not show oestrus. All ewes exhibiting normal induced cycles were in oestrus between D15 and D18, accompanying the second ovulation. The female that had a short induced cycle showed oestrus on D22, accompanying the third ovulation. The distribution of the first oestrus behaviour of the finadyne-treated females was significantly different $(P<0.01)$ from that of the control females. 
Intact ewes (group V)

(a)

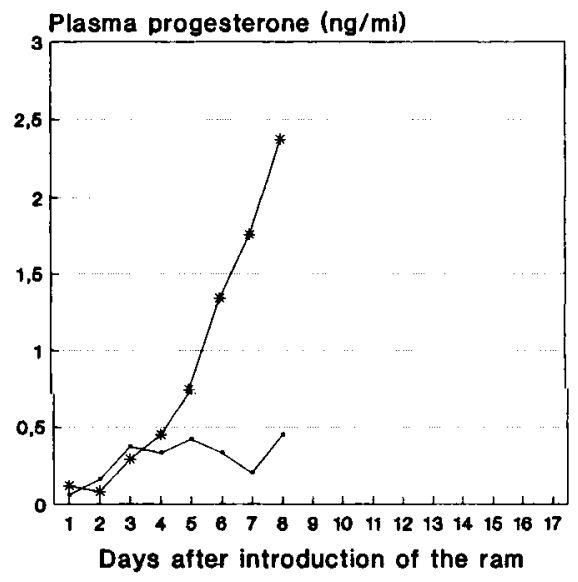

$\begin{array}{cc}- \text { short cycle } & *-\text { normal cycle } \\ n=7 & n=2\end{array}$

Hysterectomized ewes

(c)

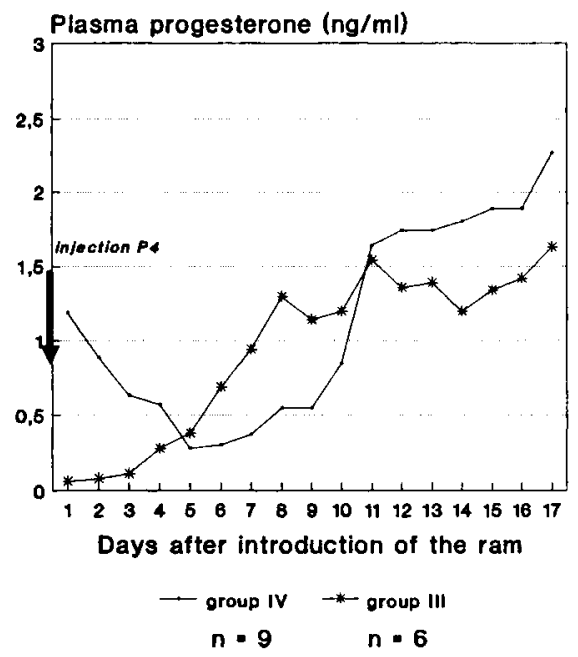

Intact ewes (group V)

(b)

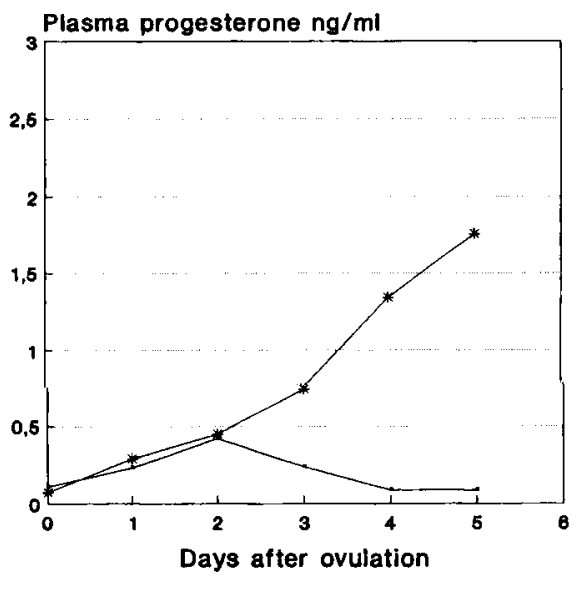

$\rightarrow$ short cycles $\rightarrow$ normal cycles

(d)

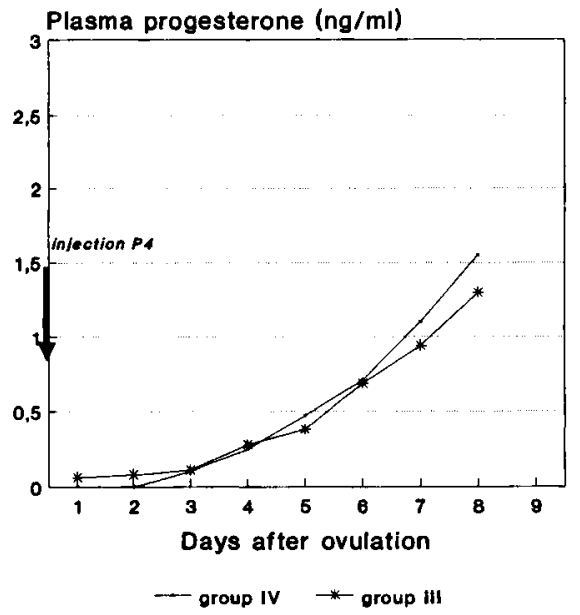

Fig 3. Plasma progesterone concentrations in intact (group V) and hysterectomized ewes, with (group IV) or without (group III) progesterone pretreatment, after ram introduction $(\mathrm{a}, \mathrm{c})$ and induced ovulation (b, d). 


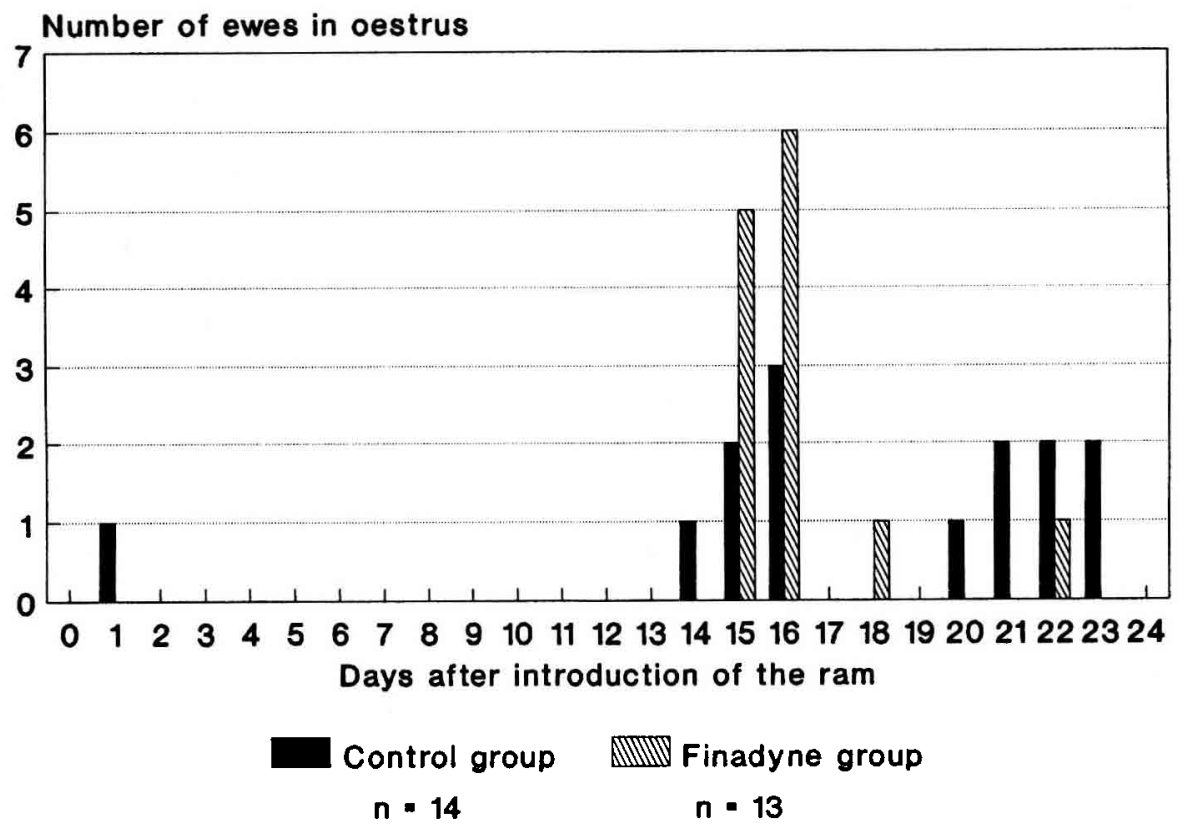

Fig 4. Distribution of first oestrus after ram introduction in control and finadyne-treated groups.

\section{Experiment 2}

All the intact females (group V) that reacted after ram introduction showed oestrus behaviour at least once. Just one came into oestrus at D6 with ovulation following a short cycle. Among the hysterectomized ewes, five showed oestrus. Two ewes, having received progesterone immediately before male introduction (group IV) showed oestrus behaviour with the induced ovulation.

\section{DISCUSSION}

The results of this study present evidence for the involvement of the uterus in early luteal failure associated with the ram effect in seasonal anovular Barbarine ewes.
Hysterectomy completely eliminated short luteal phases. These results confirm those of Chemineau et al (1993) and Southee et al (1988) obtained in Préalpes du Sud and Romney Marsh sheep, respectively.

The secretion of PGF $2 \alpha$ is implicated in this process because both the concentration and the number of pulses were significantly higher in ewes with short cycles regardless of the treatment. Furthermore, the administration of finadyne resulted in a significant reduction in PGFM production (experiment 1). When injected from D3 to D6, finadyne prevented premature luteal regression in $86 \%$ of females. Its inhibitory action on PGFM pulsatility was significant compared to the controls at D4 and D5. PGFM concentrations were low compared to those found by Battye et al (1988) in the goat. This could be due to the fact that plasma 
had been frozen without adding an inhibitor of prostaglandin degradation (Granström and Kindahl, 1982). However, as all samples (controls and treated) were treated in the same manner, and the values recorded were higher than the limit of sensibility of the assay, the effect of finadyne treatment can be considered as reliable. This treatment seemed to be more efficient than intrauterine administration of indomethacin in Barbarine sheep for 3 days (Lassoued and Khaldi, 1989). However, in sheep and cattle, the intra-uterine administration of indomethacin prevents luteal regression (Lewis and Warren, 1977) and decreases PGFM in the plasma (Troxel and Kesler, 1984).

Removal of the uterus prior to ram introduction did not change the percentage of ewes ovulating but delayed by 1 day the moment of ovulation and the increase in plasma progesterone concentrations. Ovulation was even further delayed in progesterone-treated ewes. The reasons for such a difference between intact and long-term hysterectomized females are not known. One hypothesis may be that the modifications of the ovarian vascular system by surgery have consequences for hypothalamo-pituitaryovarian feedback mechanisms.

It seems, in hysterectomized females, that progesterone secretion, as assessed by peripheral plasmatic levels, is lower than in intact ewes. Considering the very small number of intact females having a normal luteal lifespan, and the lack of knowledge about the induced ovulation rate, cellular composition and characteristics of the induced corpora lutea in hysterectomized ewes, we can not confirm that hysterectomy induced lower progesterone secretion. However, a luteotropic effect of the uterus has been demonstrated in hysterectomized ewes before ovulation induction (Southee et al, 1988) and at different moments after ovulation induction (Sankot and Murdoch, 1991). On the other hand, hysterectomized ewes were heavier than intact ones (41 versus $37 \mathrm{~kg}$ ) and Parr et al (1987) observed that overfeeding reduces peripheral progesterone concentration in sheep. This effect could be due to a higher clearance rate of progesterone since blood flow to the liver of ewes increases with feeding (Bensadoun and Reid, 1962). However, this is unlikely as when one administers intramuscularly 20 $\mathrm{mg}$ progesterone to hysterectomized ewes, the elimination of the hormone is slower (4 days, fig 3c) than in intact ewes (1 day, Lassoued et al, 1995).

Progesterone injection in hysterectomized females delayed the LH surge and ovulation but had no effect on progesterone secretion by corpora lutea during the first week. This result indicates that the timing of the preovulatory LH surge is not the most important factor in eliminating short cycles. Furthermore, this result may suggest that progesterone action is not at the ovarian level but is probably mediated through the uterus.

Luteolysis depends on oxytocin receptor concentration in the uterus (McCraken et al, 1984), which increases while plasma concentrations of progesterone decrease and oestradiol increase. In the case of induced short luteal phases in anoestrous ewes, endometrial concentrations of oxytocin receptors are higher at D5 than those found in sheep with normal induced cycles following progesterone treatment (Hunter et al, 1989). Progestagen treatment inhibits the establishment of oxytocin receptors and the release of prostaglandins in response to oxytocin administration (Vallet et al, 1990).

The length of short cycles induced by the ram effect in seasonally anoestrus ewes is remarkably constant (5-6 days). The analysis of progesterone profiles at day 4 after ram introduction or day 3 after ovulation showed a lower concentration associated with hypofunctionnel corpora lutea despite their normal appearance. This difference was not significant owing to the small num- 
ber of ewes involved in experiment 1 , but using a larger sampling of monoovulatory Barbarine ewes after ram effect $(n=68)$, a statistical difference was obtained $(0.61 \pm$ $0.29 \mathrm{ng} / \mathrm{mL}$ versus $0.48 \pm 0.32 \mathrm{ng} / \mathrm{mL} ; P<$ 0.05 ; unpublished results). This could be attributed to immaturity of the preovulatory follicle induced to ovulate by the ram effect during seasonal anoestrus. It was shown in sheep that supplementation with progesterone soon after ovulation decreases follicular growth during the first follicular wave (Rubianes et al, 1996) and probably reduces the increase in E2 secretion observed by Mattner and Braden (1972).

Thus, the lack of progesterone and its inhibitory action on oestradiol secretion and establishment of endometrial oxytocin receptors at day 5 could explain the existence of short luteal phases. The mechanism by which the uterus starts to secrete PGF $2 \alpha$ early in the cycle could then be similar to that causing corpus luteum regression at the end of a normal cycle. This phenomenon may exist in other situations such as puberty or the onset of breeding season.

\section{ACKNOWLEDGEMENTS}

This work was supported by the International Atomic Energy Agency (IAEA) and the FrancoTunisian project supported by the French Foreign Minister. We would like to thank the following people for their contributions: M Latifa Abdennebi from the Institut National Agronomique Tunisie for her assistance in statistical analysis, G Charpigny from Inra (Jouy-enJosas) for PGFM assay, A Locatelli, D André and $\mathbf{P}$ Lonergan from Prmd, Inra (Nouzilly), for, respectively, hysterectomy, LH assay and help with the English version of this manuscript.

\section{REFERENCES}

Acritopoulou S, Haresign W (1980) Responses of ewes to a single injection of an analogue of PGF $2 \alpha$ given at different stages of the oestrous cycle. $J$ Reprod Fert 58, 219-223
Battye KM, Fairclough RJ, Cameron AWN, Trounson $A O$ (1988) Evidence for prostaglandin involvement in early regression of the superovulated nanny goat (Capra hircus). J Reprod Fert 84, 425-430

Bensadoun A, Reid JT (1962) Estimation of rate of portal blood flow in ruminants; effect of feeding, fasting and anaesthesia. J Dairy Sci $45,540-543$

Brown BW, Cognié Y, Chemineau P, Poulin N, Salama OA (1988) Ovarian capillary flow in seasonally anoestrous ewes induced to ovulate by treatment with GnRH. J Reprod Fert 84, 653-658

Chemineau P (1983) Effect on oestrus and ovulation of exposing creole goats to the male at three times of the year. J Reprod Fert 67, 65-72

Chemineau P, Daveau A, Locatelli A, Maurice F (1993) Ram-induced short luteal phases: effects of hysterectomy and cellular composition of the corpus luteum. Reprod Nutr Dev 33, 253-261

Cognié Y, Gray SJ, Lindsay DR, Oldham CM, Pearce DT, Signoret JP (1982) A new approach to controlled breeding in sheep using the ram 'effect'. Proc Austr Soc Anim Prod 14, 519-522

Copelin JP, Smith MF, Garverick HA, Youngquist RS McVey WR Jr, Inskeep EK (1988) Responsiveness of bovine corpora lutea to prostaglandin $F 2 \alpha$ : comparison of corpora lutea anticipated to have short or normal lifespans. J Anim Sci 66, 12361245

Dray F, Gerozissis K, Kouznetzova B, Mamas S, Pradelles P, Trugnan G (1980) New approach to RIA of prostaglandin and compounds using iodinated tracers. Adv Prostaglandin Thromboxane Res 6, 167-180

Flint APF, Sheldrick EL, McCann TJ, Jones DSC (1990) Luteal oxytocin: Characteristics and control of synchronous episodes of oxytocin and PGF2 $\alpha$ secretion at luteolysis in ruminants. Domest Anim Endocrinol 7, 111-124

Granström E, Kindahl H (1982) Radioimmunoassay of the major metabolite of PGF $2 \alpha, 15$-keto-13,14dihydro-PGF2 $\alpha$. Methods Enzymol 86, 320-329

Hixon JE, Flint APF (1987) Effects of a luteolytic dose of oestradiol benzoate on uterine oxytocin receptor concentrations, phosphoinositide turnover and prostaglandin F2 $\alpha$ secretion in sheep. $J$ Reprod Fert 79, 457-467

Hunter MG, Southee JA, McLeod BJ, Haresign W (1986) Progesterone pretreatment has a direct effect on GnRH-induced preovulatory follicles to determine their ability to develop into normal corpora lutea in anoestrous ewes. $J$ Reprod Fert 76, 349363

Hunter MG, Ayad VJ, Gilbert CL, Southee JA, Wathes DC (1989) Role of prostaglandin F-2 $\alpha$ and oxytocin in the regression of $\mathrm{GnRH}$-induced abnormal corpora lutea in anoestrous ewes. $J$ Reprod Fert $85,551-556$

Khaldi G (1984) Variations saisonnières de l'activité ovarienne, du comportement d'oestrus et de la durée 
de l'anoestrus post-partum des femelles ovines de race Barbarine: influence du niveau alimentaire et de la présence du mâle. Thèse Doct ès Sciences, UST Languedoc

Knight TW, Peterson AJ, Payne E (1978) The ovarian and hormonal response of the ewe to stimulation by the ram early in the breeding season. Theriogenology, 10, 343-353

Knight TW, Tervitt HR, Fairclough RJ (1981) Corpus luteum function in ewes stimulated by rams. Theriogenology 15, 183-190

Lassoued N, Khaldi G (1989) Influence de l'indométacine sur la durée du cycle ovarien induit par effet mâle chez la brebis. Ann INRA Tunisie 62,16

Lassoued N, Khaldi G (1993) Etudes sur l'influence du niveau alimentaire avant et après la mise-bas sur la réponse des brebis de race Barbarine à l'effet mâle en Tunisie. Improving the productivity of indigenous African livestock. Results of FAO/IAEA/DGIS Co-ordinated Research Programmes organized by the Joint FAO/LAEA Division of Nuclear Techniques in Food and Agriculture, IAEA-TECDOC-708, 59-66

Lassoued N, Khaldi G, Cognié Y, Chemineau P, Thimonier J (1995) Effet de la progestérone sur le taux d'ovulation et la durée du cycle ovarien induits par effet mâle chez la brebis Barbarine et la chèvre locale tunisienne. Reprod Nutr Dev 35, 415-426

Lewis PE, Warren JE Jr (1977) Effect of indomethacin on luteal function in ewes and heifers. J Anim Sci 46, 763-767

Lindsay DR, Cognié Y, Signoret JP (1982) Méthode simplifiée de maîtrise de l'oestrus chez la brebis. Ann Zootech 31, 77-82

Martin GB, Scaramuzzi RJ, Oldham CM, Lindsay DR (1983) Effects of progesterone on the responses of merino-ewes to the introduction of rams during anoestrus. Austr J Biol Sci 36, 369-378

Mattner PE, Braden AWH (1972) Secretion of oestradiol $-17 \beta$ by the ovine ovary during the luteal phase of the oestrous cycle in relation to ovulation. $J$ Reprod Fert 28, 136-137

McCracken JA, Shramm W, Okulicz WC (1984) Hormone receptor control of pulsatile secretion of PGF2 $\alpha$ from the ovine uterus during luteolysis and its abrogation in early pregnancy. Anim Reprod Sci 7, 31-55

McLeod BJ, Haresign W (1984) Evidence that progesterone may influence subsequent luteal function in the ewe by modulating preovulatory follicle development. J Reprod Fert 71, 381-386

Merriam GR, Wachter KW (1982) Algorithms for the study of episodic hormone secretion. Am J Physiol 243, E310-318

Montgomery GW, Martin GB, Pelletier J (1985) Changes in pulsatile LH secretion after ovariec- tomy in Ile de France ewes in two seasons. $J$ Reprod Fert 73, 173-183

Oldham CM (1980) Stimulation of ovulation in seasonally or lactationally anovular ewes by rams. Proc Aust Soc Anim Prod 13, 73-86

Oldham CM, Lindsay DR (1980) Laparoscopy in the ewe: a photographic record of the ovarian activity of ewes experiencing normal or abnormal oestrous cycle. Anim Reprod Sci 3, 119-124

Parr RA, Davis IF, Fairclough RJ, Miles MA (1987) Overfeeding during early pregnancy reduces peripheral progesterone concentration and pregnancy rate in sheep. $J$ Reprod Fert 80, 317-320

Pelletier J, Garnier DH, De Reviers MM, Terqui M, Ortavant R (1982) Seasonal variation in LH and testosterone release in rams of two breeds. $J$ Reprod Fert 64, 341-346

Peterson AJ, Tervit HR, Fairclough RJ, Havik PG, Smith JF (1976) Jugular levels of 13, 14 dihydro15-keto-prostaglandin $\mathrm{F}$ and progesterone around luteolysis and early pregnancy in the ewe. Prostaglandins 12, 551-558

Roberts JS, McCracken JA, Gavagan JE, Soloff MS (1976) Oxytocin-stimulated release of prostaglandin $\mathrm{F} 2 \alpha$ from ovine endometrium in vitro: correlation with estrous cycle and oxytocin-receptor binding. Endocrinol 99, 1107-1114

Rubianes E, de Castro T, Carbajal B (1996) Effect of high progesterone levels during the growing phase of the dominant follicle of wave 1 in ultrasonically monitored ewes. Can J Anim Sci 76, 473-475

Sankot AP, Murdoch WJ (1991) Luteotropic influence of the ovine uterus. Dom Anim Endocrinol 8, 369375

Sheldrick EL, Flint APF (1985) Endocrine control of uterine oxytocin receptors in the ewe. $J$ Endocr 106, 249-258.

Southee JA, Hunter MG, Law AS, Haresign W (1988) Effect of hysterectomy on the short life-cycle corpus luteum produced after GnRH-induced ovulation in the anoestrous ewe. $J$ Reprod Fert $84,149-155$

Thimonier J (1978) L'activité ovarienne chez les bovins. Moyens d'étude et facteurs de variation. Ann Med Vet 122, 81-92

Troxel TR, Kesler DJ (1984) Ability of indomethacin to alter prostaglandin metabolite concentrations and to enhance the function of corpora lutea induced in postpartum suckled beef cows. J Anim Sci 59 , $1,177-181$

Vallet JL, Lamming GE, Batten M (1990) Control of endometrial oxytocin receptor and uterine response to oxytocin by progesterone and oestradiol in the ewe. J Reprod Fert 90, 625-634

Zarco L, Stabenfeldt GH, Kindahl H, Quirke JF, Granström E (1984) Persistence of luteal activity in the non-pregnant ewe. Anim Reprod Sci 7, 245-267 